\title{
ELECTROCHEMICAL BEHAVIOR OF VULPINIC ACID AT GLASSY CARBON ELECTRODE
}

Luane Ferreira Garcia* e Eric de Souza Gil

Faculdade de Farmácia, Universidade Federal de Goiás (UFG)

*E-mail: luane.fg@hotmail.com
Submetido em: 15/04/2015

Aceito em: 16/06/2015

Publicado em: 30/09/2015

\begin{abstract}
The electrochemical redox behavior of vulpic acid, a lichen derivative, mainly investigated by its antibiotic activity was carried out in aqueous electrolytes at glassy carbon electrode. This investigation was developed by using cyclic, differential pulse and square wave voltammetry in a wide range of $\mathrm{pH}$. Thus, the electrochemical oxidation of vulpic acid showed to occur in a single anodic and irreversible process with strong adsorption of oxidation products. The oxidation of adsorbed species leads to a second anodic peak, meanwhile the first anodic peak decreases intensely. Such events showed to be higher in non-neutral pH, and should be associated to hydrolysis of lactone.
\end{abstract}

Keywords: Lichens, antibiotic, voltammetric analysis.

\section{Comportamento Eletroquímico do Ácido Vulpínico em Eletrodo de Carbono Vítreo}

\section{Resumo}

O ácido vulpínico é um produto extracelular de liquens que apresenta atividade antibiótica. O comportamento eletroquímico deste composto foi obtido com eletrodos de carbono vítreo em eletrólito aquoso. As análises foram realizadas por voltametria cíclica, pulso diferencial e onda quadrada, em uma ampla faixa de pH. A oxidação eletroquímica do ácido vulpínico demonstrou ter ocorrido em um único processo anódico e irreversível, com uma forte adsorção dos produtos de oxidação. As espécies adsorvidas conduziram a um segundo pico anódico, enquanto isso o primeiro pico anódico diminui intensamente. Tais eventos foram maiores em pH não-neutro, e podem estar associados à hidrólise da lactona.

Palavras-chave: Liquens, antibiótico, análises voltamétricas.

\section{Comportamiento Electroquímico del Ácido Vulpínico en Electrodo de Carbono Vítreo}

\section{Resumen}

El ácido vulpínico es un producto extracelular de los líquenes, que presentan actividad antibiótica. El comportamiento electroquímico de este compuesto se obtuvo con electrodos de carbón vítreo en electrolito acuoso. Los análisis se realizaron mediante voltametría cíclica, pulso diferencial y de onda cuadrada, en un amplio rango de pH. La oxidación electroquímica de ácido vulpínico se ha demostrado en un solo proceso anódico e irreversible, con una fuerte adsorción de productos de oxidación. Las especies adsorbidas condujeran a un segundo pico anódico, mientras que el primer pico anódico disminuye intensamente. Estos eventos fueron más altos en pH no neutro y pueden estar asociados con la hidrólisis de la lactona.

Palabras clave: Líquenes, antibióticos, análisis voltamétrica. 


\section{INTRODUCTION}

Together with plants, lichens are one of the main sources of natural products, whose interest is governed by a wide range of biotechnological applications, i.e. Pharmaceutical, Cosmetic, Dyes, and poisons ${ }^{(1-6)}$. The organic compounds produced by lichens can be divided into two groups: primary metabolites and secondary metabolites. Among the well-known secondary metabolites is vulpinic acid $(\mathrm{VA})^{(7)}$.

Chemically, VA, methyl 2-(3,5-dioxo-4-phenyl-2-furylidene)-2-phenylacetate is an ethanol soluble bright yellow pigment ${ }^{(8)}$. Also named as vulpic acid, VA is found in wide variety of lichen and mushrooms species ${ }^{(9,10)}$

Owing to its diverse biological activities, lichens containing VA have a strong history of medicinal use ${ }^{(11)}$. As in the case of usnic acid, the most extensively studied lichen metabolite, VA has been also speculated by its antibiotic and antiproliferative activity $^{(1,2,5)}$

Although, the antimicrobial and antiproliferative activities of VA showed to be significantly higher against Gram-positive bacteria $^{(12,13)}$, the toxicity of VA against mammalian cells is not negligible. As an example, it was also found that vulpinic acid was an effective antiherbivorous, being used as a grazing insects or invertebrates repellent ${ }^{(14)}$. Meanwhile, lichens extracts containing high amounts of VA, i.e. Lethariavulpina and Vulpicidapinastri were used by Eskimos to poison wolves in Northern Europe. Notwithstanding, the large amounts of VA and pinastric acid, both natural dyes, confer to such lichen species their yellow color. Thus, the dyes and toxicological properties of VA and its derivatives have attracted the attention of the scientific community $(8,13,14)$.

However, despite its inherent toxicity, VA, and its derivatives have displayed anti-inflammatory activity, meanwhile the therapeutic ratio was moderately good ${ }^{(9,13)}$.

On the other hand, VA and chemical congeners have exhibited strong antioxidant activity. The antioxidant properties of several VA analogs were evaluated using spectrometric assays, i.e. ABTS and DPPH free radical scavenging assays. The importance of the central tetronic ring (Figure 1), whose central heterocyclic ring resembles ascorbic acid (AA) was evidenced ${ }^{(15)}$.

Figure 1: Chemical structure of vulpinic acid (VA) and ascorbic acid (AA).
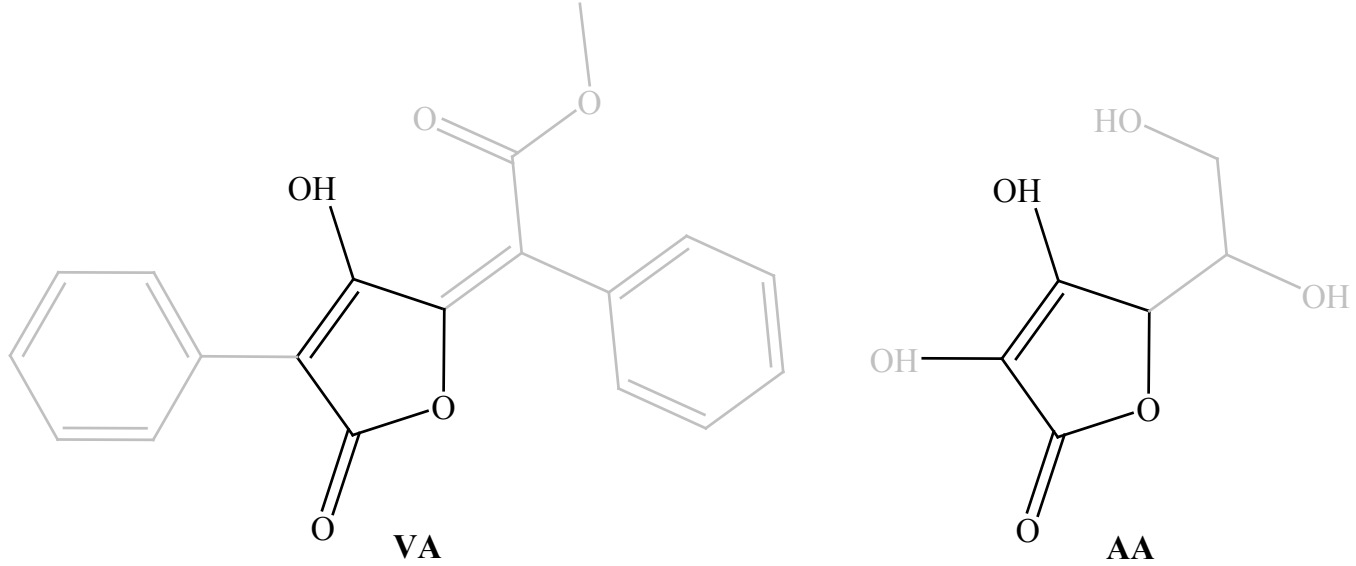
Such biological properties are often related to a well-defined chemical structural pattern but they deserve further research ${ }^{(4,15)}$.

However, in spite of all promising applications of VA, the studies concerning its physicochemical properties are scarce and outdated $^{(16,17)}$.

The electroanalytical assays leading to the determination of physicochemical parameters, e.g., redox potential, the number of electrons transferred, electrode-reaction rate constant, are a relevant tool to characterize chemical compounds ${ }^{(18)}$. Furthermore, the understanding of the redox behavior is of fundamental importance for species with recognized antioxidant activity $^{(19,20)}$. On the other hand, such studies may also provide useful data for the development of electroanalytical methods.

\section{EXPERIMENTAL}

\subsection{Materials and Reagents}

The VA was obtained from Extrasynthese (Genay, France) and used without further purifications. All supporting electrolyte solutions were prepared using analytical grade reagents and purified water from a Millipore Milli-Q system (conductivity $\left.\leq 0.1 \mu \mathrm{S} \mathrm{cm}^{-1}\right)$.

Microvolumes were measured using EP-10 and EP-100 Plus Motorized Microliter Pippettes (Rainin Instrument Co. Inc., Woburn, USA).

The pH measurements were carried out using a CrisonmicropH 2001 pH-meter with an Ingold combined glass electrode.

\subsection{Voltammetric Parameters and Electrochemical Cells}

Voltammetric experiments were carried out using an Autolab PGSTAT 30 running with GPES 4.9 software, (EcoChemie, Utrecht, The Netherlands), and a three-electrode system in a $1.0 \mathrm{~mL}$ compartment electrochemical cell of capacity $2 \mathrm{ml}$ (Cypress System Inc., USA). Glassy carbon electrode, GCE $(d=1.5 \mathrm{~mm})$ was the working electrode, Pt wire the counter electrode, and the $\mathrm{Ag} / \mathrm{AgCl}(3 \mathrm{M} \mathrm{KCl})$ reference electrode.

In order to ensure the reproducibility of results, the GCE was polished using diamond spray (particle size $3 \mu \mathrm{m}$ ) before each experiment. After polishing, it was rinsed thoroughly with Mille-Q water. Following this mechanical treatment, the GCE was placed in buffer supporting electrolyte and voltammograms were recorded until a steady state baseline was obtained.

The experimental conditions for differential pulse voltammetry were: pulse amplitude $50 \mathrm{mV}$, pulse with $70 \mathrm{~ms}$, and scan rate $5 \mathrm{mV} \mathrm{s}^{-1}$. For square wave voltammetry a frequency of $75 \mathrm{~Hz}$ and a potential increment of $2 \mathrm{mV}$, corresponding to an effective scan rate of $100 \mathrm{mVs}^{-1}$ were used.

The electrochemical experiments were done at room temperature $\left(25 \pm 1^{\circ} \mathrm{C}\right)$ in different $\mathrm{pH}$ supporting electrolytes.

\subsection{Acquisition and Presentation of Voltammetric Data}

The differential pulse voltammograms presented were background-subtracted and baseline-corrected using the moving average application with a step window of $5 \mathrm{mV}$ included in GPES version 4.9 software. This mathematical treatment improves the visualization and identification of peaks over the baseline without introducing any artifact, although the peak intensity is, in some cases, reduced $(<10 \%)$ relative to that of untreated curve. Nevertheless, this mathematical treatment of the original was used for all experimental voltammograms for a better and clearer identification of the peaks. The values for peak current presented in all plots were determined from the original untreated voltammograms after subtraction of baseline. 


\section{RESULTS AND DISCUSSION}

The cyclic voltammogram obtained for $30 \mu \mathrm{mol} \mathrm{L}^{-1} \mathrm{VA}$ in $\mathrm{pH} 8.0$ showed two anodic peaks, $1 \mathrm{a}$ and $2 \mathrm{a}$, at $E_{\mathrm{p} 1 \mathrm{a}}=0.55 \mathrm{~V}$ and $E_{\mathrm{p} 2 \mathrm{a}}=1.1 \mathrm{~V}$, on the reverse scan the corresponding cathodic peak cannot be observed in such conditions. After successive scans, the peak current falls intensely, showing strong adsorption process leading to the blockade of electrode surface (Figure $2 \mathrm{~A}$ ).

When the scans were performed on the inverse direction from $1.1 \mathrm{~V}$ to $-0.25 \mathrm{~V}$ except, one reduction peak was observed at $E_{\mathrm{p} 1 \mathrm{c}}=0.1 \mathrm{~V}$ (Figure $2 \mathrm{~B}$ ). On the reverse scan, one anodic peak, $1 \mathrm{a}$, appears at $E_{\mathrm{pa} 1}=0.65 \mathrm{~V}$.

The adsorptive behavior of VA was more evidenced in DPV experiments, where successive scans were performed without cleaning the electrode surface. Thus, it can be observed in Figure 3, that the peak currents, $I_{\mathrm{p} 1 \mathrm{a}}$ of peak $1 \mathrm{a}$ at $E_{\mathrm{p} 1 \mathrm{a}} \sim 0,5 \mathrm{~V}, \mathrm{pH}$ 4.0 are progressively decreased and shifted to more positive peak potentials, meanwhile a second anodic peak, $2 \mathrm{a}$ appears at $E_{\mathrm{p} 2 \mathrm{a}} \sim 0.74 \mathrm{~V}$.

Also, the adsorption was strongly enhanced in higher molar concentrations, thus leading to very short linear range and low accuracy for quantitative analysis of this natural product (Figure 3 B).

Figure 2: Cyclic voltammograms obtained for $35 \mu \mathrm{mol} \mathrm{L} \mathrm{L}^{-1} \mathrm{VA}$ in $0.1 \mathrm{~mol} . \mathrm{L}^{-1}$ phosphate buffer, $\mathrm{pH} 8.0$ (A) or $0.1 \mathrm{~mol}^{-\mathrm{L}^{-1}}$ acetate buffer, $\mathrm{pH} 4.0(\mathrm{~B}) ;(-)$ first, $(---)$ second and $(\boldsymbol{\cdots})$ third scans at $v=100 \mathrm{mV} \mathrm{s}^{-1}$. Scan range from 0 to $+1.25 \mathrm{~V}(\mathrm{~A})$ or from +1.1 to $-0.25 \mathrm{~V}(\mathrm{~B})$.

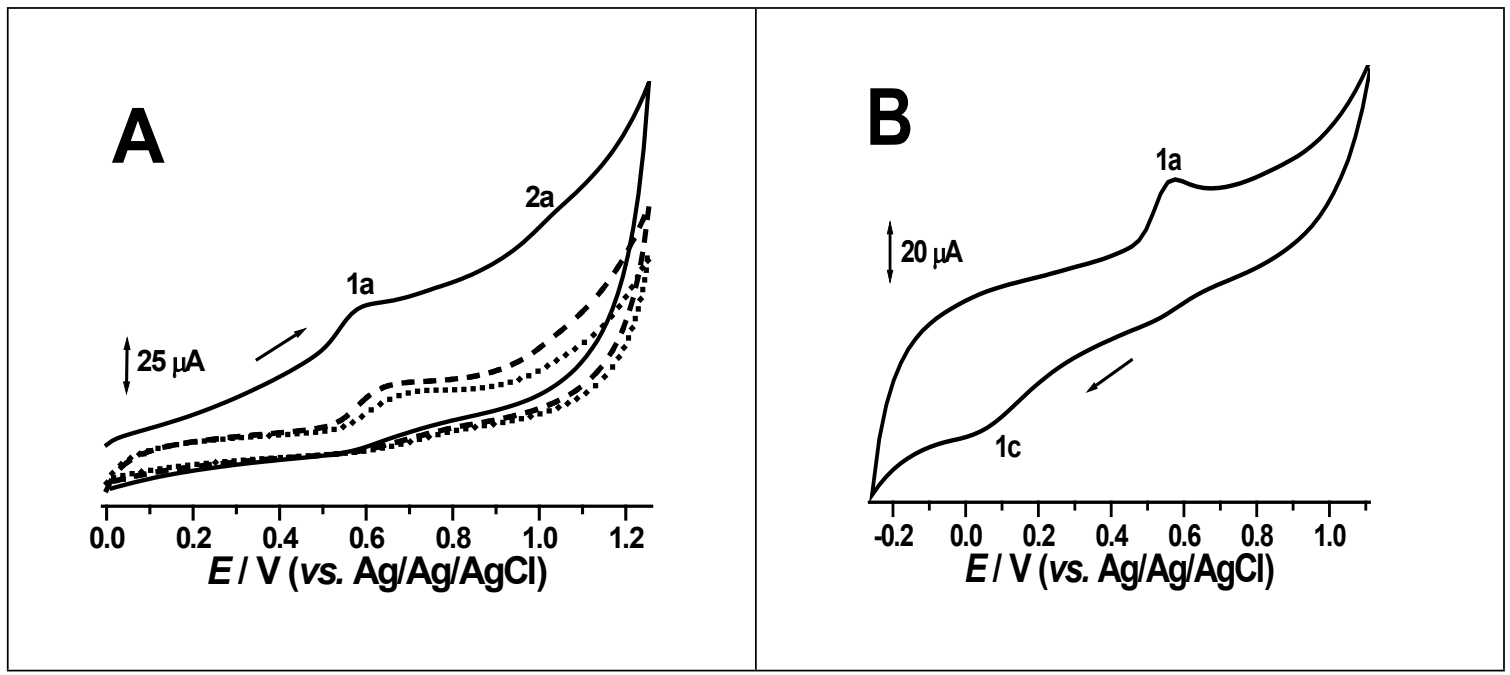


Figure 3: (A): DP voltammograms base-line corrected of $20 \mu \mathrm{M}$ VA obtained in pH 4.00 .1 mol.L-1 acetate buffer;

$(-)$ first scan, (- - ) second scan, ( $\bullet \bullet$ ) third scan, (- - -) forth scan, and (- - - -) fifth scan.

(B): Calibration graph obtained for successive increasing concentrations of VA by DPV.

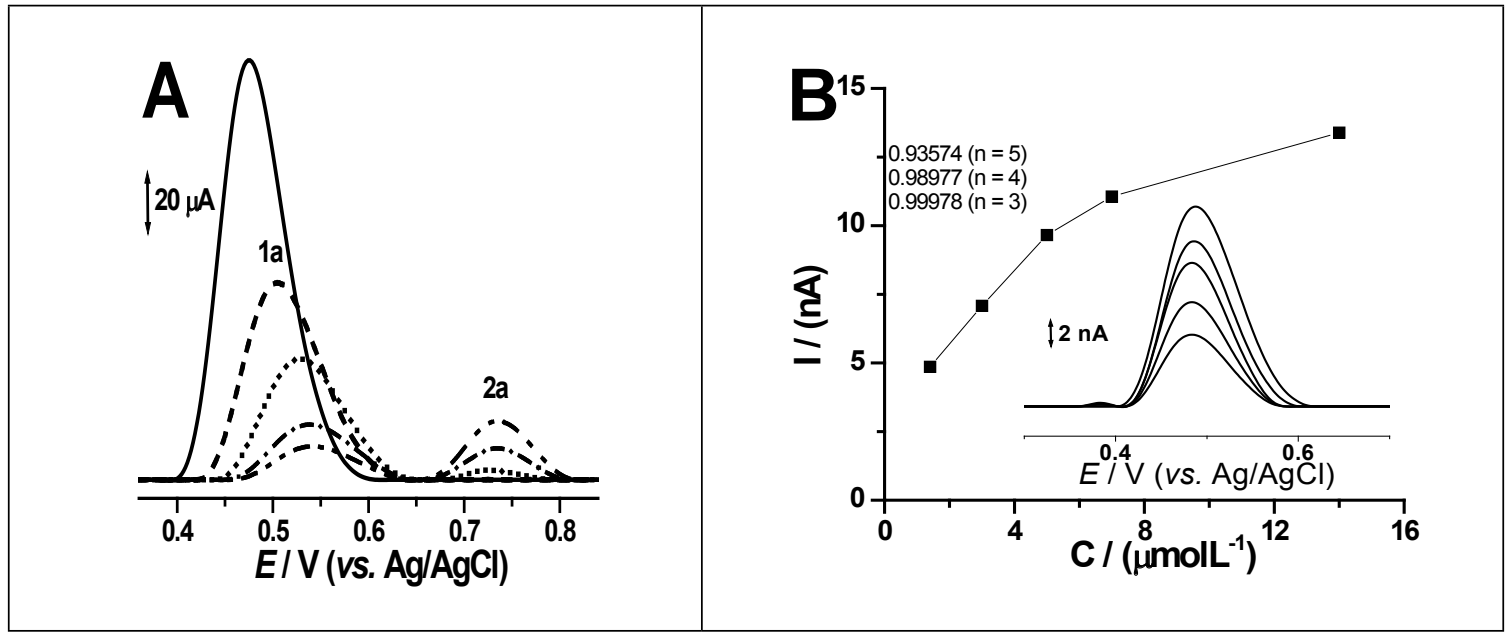

The strong adsorptive behavior, as well the appearance of an anodic peak, $2 a$ only at the second scan, suggest the generation of electroactive oxidation products (Figure 3A).

The $\mathrm{pH}$ dependence was also evaluated by DPV, and it has shown that peak potentials decrease linearly up to $\mathrm{pH} 6.0$, then it becomes almost constant. The 3D plot as well the $E_{\mathrm{p}}, l_{\mathrm{p}} \mathrm{vs}$. pH plot are shown on Figure 4.

The slope of $30 \mathrm{mV} / \mathrm{pH}$ is very distant from the theoretical value of $59 \mathrm{mV} / \mathrm{pH}$ for equal involvement between protons and electrons. Indeed, the electro-oxidation of VA showed to be very complex in nature, in which hydrolytic and polymeric reactions may exert some influence. The adsorption process was also expressive at higher scan rates, as it can be seen in the deformed SW voltammograms (Figure 5).

Figure 4: 3D plot of DP voltammograms base-line corrected (A) and $E_{\mathrm{p}}, I_{\mathrm{p}} v s . \mathrm{pH}$ plots (B) obtained for $30 \mu \mathrm{mol} . \mathrm{L}^{-1} \mathrm{VA}$ in different $\mathrm{pH}$ solutions.

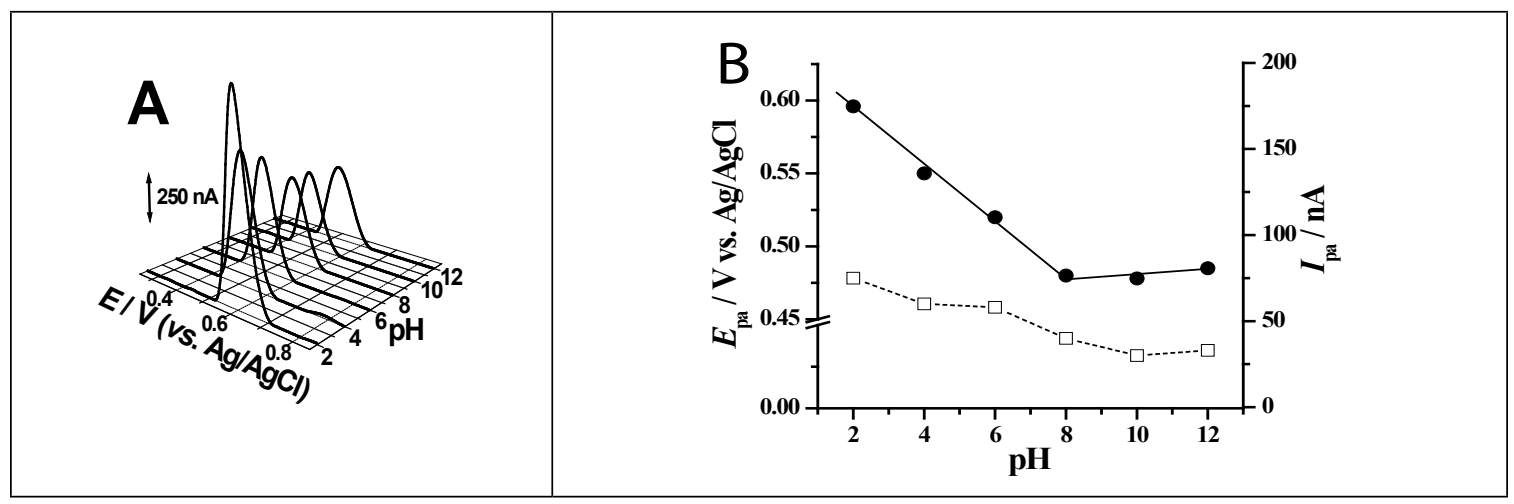


Figure 5: SW voltammograms of $40 \mu \mathrm{M}$ vulpinic acid in $\mathrm{pH}=7.00 .1 \mathrm{M}$ phosphate buffer; $f=50 \mathrm{~Hz}, \Delta E_{\mathrm{s}}=2 \mathrm{mV}$, $v_{\text {eff }}=100 \mathrm{mV} \mathrm{s}^{-1} ; I_{\mathrm{t}}$ - total, $I_{\mathrm{f}}$ - forward and $l_{\mathrm{b}}$-backward.

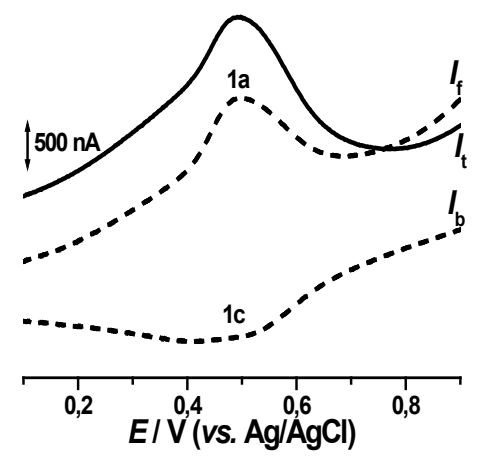

Moreover, it was also observed on SWV experiments, that the forward and backward currents are almost equivalent, which implies that the process is quasi-reversible. Therefore, the changing of electrode surface caused by adsorptive process not only reduces the anodic peaks observed on successive scans but also jeopardizes the observation of the correspondent cathodic peak on CV. The proposed mechanism is presented on Figure 6.

Figure 6: A proposed mechanism for the electrochemical oxidation of VA.
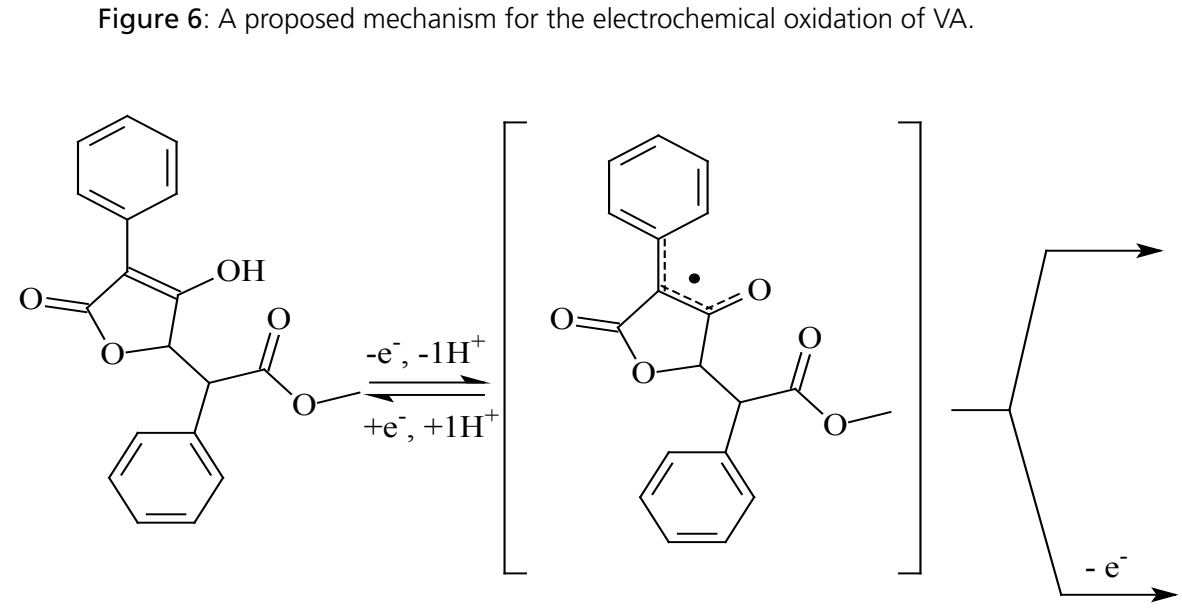<smiles>COC(=O)C(c1ccccc1)C1OC(=O)C(c2ccccc2)C1=O</smiles>

\section{CONCLUSION}

The electrochemical behavior of vulpic acid was carried with glassy carbon electrodes and showed to occur in a single anodic and irreversible process, with strong adsorption of oxidation products. It is concluded that such events may be associated with hydrolysis of the lactone. 


\section{REFERENCES}

1. Lawrey JD. Biological role of lichen substances. Bryologist.1986;89:111-122.

2. Lauterwein M, Oethinger M, Belsner K, Peters T, Marre R. In vitro activities of the lichen secondary metabolites vulpinic acid, (+)-usnic acid and (-)-usnic acid against aerobic and anaerobic microorganisms. Antimicrob. Agents Chemother.1995;39:2541-2543.

3. Barnes J. Pharmacognosy in the 21st century. Pharm J. 2000;264:701-703.

4. Müller K. Pharmaceutically relevant metabolites from lichens.Appl. Microbiol. Biotech. 2001;56:9-6.

5. Cochietto M, Skert N, Nimis PL, Sava G. A review on uscinic acid, an interesting natural compound. Naturwissenchaften. 2002;89(4):137-146.

6. Anar M, Kizil HE, Agar G. The determination of antioxidative effect and anticancer potential of vulpinic acid. Journal of biotechnology. 2014;185:s107.

7. Türk AÖ, Yilmaz M, Kivanç M, Türk H. The antimicrobial activity of extracts of the lichen Cetrariaaculeata and its protolichesterinic acid constituent. Verlag der ZeitschriftfürNaturforschung. 2003;58:850-854.

8. Kanokmedhakul S, Kanokmedhakul K, Prajuabsuk T, Soytong K, Kongsaeree P, Suksamrarn A. A bioactive triterpenoid and vulpinic acid derivatives from the mushroom Schlerodermacitrinum. Planta Med. 2003;69(6):568-571.

9. Honda NK, Vilegas W. A química dos líquens. Quím. Nova. 1999;22(1):110-125.

10. Mattsson JE, Lai MJ. Vulpicida, a new genus in parmeliaceae (Lichenized Ascomycetes). Mycotaxon. 1993;46:425-428.

11. Shukla V, Joshi GP, Rawat MSM. Lichens as a potential natural source of bioactive compounds: a review. Phytochemistry Reviews. 2010;9(2):303-314.

12. Nadir MT, RashanLJ, AyoubMT, AwniLT. Antibacterial and antiproliferative activities of vulpinic acids in vitro. Farmaco. 1992;47(5):643-647.

13. Bourdreux Y, Bodio E, Willis C, Billaud C, Gall T, Mioskowski C. Synthesis of vulpinic and pulvinic acids from tetronic acid. Tetrahedron. 2008;64:8930-8937.

14. Emmerich R,Giez I, Lange OL, ProkschP. Toxicity and antifeedant activity of lichen compounds against the polyphagous herbivorous insect Spodopteralittoralis. Phytochem. 1993;33(6):1389-1394.

15. Nadal B, Sophie AL, Laurent T, Pin S, Renault JP, Cressier D, et al. Synthesis and antioxidant properties of pulvinic acids analogues. Bioorg. Med. Chem. 2010;18:7931-7939.

16. Arup U, Ekman S, Lindblom L, Mattsson J-E. High performance thin layer chromatography (HPTLC), an improved technique for screening lichen substances. Lichenologist. 1993;25(1):61-71.

17. Yoshimura I, Kinoshita Y, Yamamoto Y, Huneck S,Yamada Y. Analysis of secondary metabolites from Lichen by high performance liquid chromatography with a photodiode array detector. Phytochem. Anal. 1994;5: 197-205.

18. Gil ES, Couto RO. Flavonoid electrochemistry: a review on the electroanalytical applications. Brazilian Journal of Pharmacognosy. 2013;23(3):542-558. 
19. Reis NS, SerranoSHP, MeneghattiR, GilES. Métodos eletroquímicos usados para avaliação da atividade antioxidante de produtos naturais. Lat. Am. J. Pharm. 2009;28(6):949-53.

20. Jorge SMA, Pontinha ADR, Marques MPM, Oliveira-BrettAM. Solid state electrochemical behavior of usnic acid at a glassy carbon electrode. Anal. Lett. 2010;43:1713-1722.

Acknowledgement: CNPq financial support, Projeto Universal 2013. 